\title{
IMPLEMENTASI KEBIJAKAN PENANGGULANGAN BENCANA MELALUI PROGRAM SMART DI KELURAHAN SISIR KOTA BATU
}

\author{
Dody Setyawan, M. Okto Adithama, Firda Mariana AM \\ Program Studi Ilmu Administasi Negara, FISIP, Universitas Tribhuwana Tunggadewi \\ Jl.Telaga Warna Blok C, Tlogomas, Kec. Lowokwaru, Kota Malang. \\ Email: dody.setyawan@unitri.ac.id
}

\begin{abstract}
Indonesia is one of countries that most vulnerable to disaster in the world. The high rank of Indonesia is calculated from the number of people who are at risk of losing their lives due to the disaster. To reduce this, a disaster management policy is needed, namely through Program Sisir Siaga Mandiri Relawan Tangguh (SMART). The SMART program is a synchronization between the Tangguh and Siaga Villages which are two community institutions based on community service. This study aimed to describe the implementation of disaster management policies through the SMART program in Kelurahan Sisir, Kecamatan Batu District, Batu. This study used a qualitative method with the data collection techniques through interviews, observation, and documentation. To determine the informant, it used a purposive sampling technique. While the data analysis involved data reduction, presentation, and conclusion. The validity test was done by triangulation techniques. The results of the study showed that the implementation of disaster management policies through the SMART Program in Sisir Village was categorized as effective. It can be seen from the George C Edward III Policy Implementation Model which included communication, resources, dispositions or attitudes, and bureaucratic structures. The supporting factors were the existence of support from the community and BPBD, as well as cooperation with related agencies. While the inhibiting factors were the lack of synergy between the government and the community, and the lack of personnel and supporting equipment at the time of evacuation in the field.
\end{abstract}

Keywords: Policy Implementation, Disaster Management, SMART.

Abstrak: Indonesia merupakan salah satu negara yang paling rawan terhadap bencana di dunia. Tingginya posisi Indonesia dihitung dari jumlah manusia yang terancam kehilangan nyawa akibat bencana. Untuk mengurangi hal tersebut, maka diperlukan kebijakan penanggulangan bencana yaitu melalui Program Sisir Siaga Mandiri Relawan Tangguh (SMART). Program SMART merupakan sinkronisasi antara Kelurahan Tangguh dan Kelurahan Siaga yang merupakan dua lembaga kemasyarakatan berbasis pada pelayanan masyarakat. Penelitian ini bertujuan untuk mendeskripsikan implementasi kebijakan penanggulangan bencana melalui program SMART di Kelurahan Sisir Kecamatan Batu Kota Batu. Penelitian ini menggunakan metode kualitatif. Teknik pengumpulan data melalui wawancara, observasi, dan dokumentasi dengan teknik penentuan informan menggunakan purposive sampling. Analisis data menggunakan reduksi data, penyajian data, dan penarikan kesimpulan. Uji keabsahan data menggunakan trianggulasi teknik. Hasil penelitian Implementasi Kebijakan Penanggulangan Bencana melalui Program SMART di Kelurahan Sisir dapat dikatakan sudah efektif, dilihat dari Model Implementasi Kebijakan George C Edward III yaitu meliputi komunikasi, sumber daya, disposisi atau sikap, dan struktur birokrasi. Faktor pendukungnya yaitu adanya dukungan dari masyarakat dan BPBD, serta kerja sama dengan dinas-dinas terkait. Sedangkan Faktor Penghambatnya yaitu kurangnya sinergitas antara pemerintah dan masyarakat, serta kurangnya tenaga relawan dan peralatan pendukung pada saat evakuasi dilapangan.

Kata Kunci: Implementasi Kebijakan, Penanggulangan Bencana, SMART. 


\section{PENDAHULUAN}

Indonesia merupakan salah satu negara yang paling rawan terhadap bencana di dunia (www.bnpb.go.id, 2017), berdasarkan data Badan Perserikatan Bangsa-Bangsa (PBB) untuk Strategi Internasional Pengurangan Risiko Bencana (UN-ISDR) tingginya posisi Indonesia dihitung dari jumlah manusia yang terancam risiko bencana, (www.bnpb.go.id 2017). Badan Nasional Penanggulangan Bencana (BNPB) Indonesia dalam laporannya menyebutkan bahwa terdapat 1.227 bencana alam terjadi di negeri ini pada Tahun 2018 dan tercatat ada sebanyak 3.548 orang meninggal dunia dan hilang, 13.112 orang luka-luka, serta 3,06 juta jiwa mengungsi dan terdampak bencana, (www.bnpb.go.id, 2018).

Menurut Undang-undang Nomor 24 tahun 2007 tentang Penanggulangan Bencana Pasal 1 ayat 1 menyebutkan bahwa bencana adalah peristiwa yang mengancam dan mengganggu kehidupan masyarakat yang disebabkan, baik oleh faktor alam, faktor non alam, dan faktor manusia yang mengakibatkan timbulnya korban jiwa, kerusakan lingkungan, kerugian harta benda, dan dampak psikologis. Bencana terjadi karena ada ancaman, dampak, dan kerentanan. Bencana juga dapat mengancam semua wilayah di Indonesia baik di wilayah daratan, pesisir pantai, maupun di daerah pegunungan termasuk Wilayah Jawa Timur khususnya Kota Batu, (www.bpbdjatim.go.id, 2018). Salah satu kelurahan di Kota Batu yang memiliki potensi bencana yang besar adalah wilayah Kelurahan Sisir, berdasarkan data yang diperoleh dari Badan Penanggulangan Bencana Daerah (BPBD) Kota Batu dan Pemerintah Kelurahan Sisir pada Tahun 2018 tercatat beberapa wilayah di Kelurahan Sisir yang mengalami bencana seperti pada Rukun Warga (RW).12 dan RW.11 terjadi Tanah Longsor, pada RW.01 dan RW.03 terjadi Tanah Amblas, RW.2, RW.7, RW.8 terjadi Banjir, dan RW.10 terjadi kebakaran, (www.bpbdkotabatu.go.id, 2018).

Pemerintah dalam hal ini bertanggung jawab melindungi segenap warganya dengan tujuan untuk memberikan perlindungan atas kehidupan dan penghidupan seperti perlindungan terhadap bencana dalam rangka terwujudnya kesejahteraan umum, sebagaimana diamanatkan pada Pembukaan Undang-Undang Dasar Negara Republik Indonesia Tahun 1945. Selain itu, pemerintah juga memiliki peran untuk melakukan manajemen bencana sebagai sebuah usaha kompleks yang mencakup tugas mulai dari prediksi bencana dan kesiapan jangka panjang pemulihan dan rekonstruksi serta manajemen risiko bencana di masa depan, (Paltema, 2017: 13).

Untuk mengurangi resiko bencana, maka diperlukan kebijakan penanggulangan bencana. Kebijakan adalah segala sesuatu yang dipilih oleh pemerintah untuk dilakukan atau tidak dilakukan dalam rangka mencapai tujuan dan sasaran dari program-program pemerintah dan ditujukan untuk kepentingan masyarakat, (Setyawan, 2017:20). Berdasarkan Undang-undang Nomor 24 tahun 2007 tentang Penanggulangan Bencana Pasal 1 ayat 5 menyebutkan bahwa penyelenggaraan penanggulangan bencana adalah serangkaian upaya yang meliputi penetapan kebijakan pembangunan yang dapat menimbulkan bencana, kegiatan pencegahan bencana, tanggap darurat, dan rehabilitasi. Kemudian berdasarkan Peraturan Daerah Kota Batu Nomor 2 tahun 2015 tentang Penyelenggaraan Penanggulangan Bencana Pasal 1 ayat 9 menyebutkan bahwa penanggulangan bencana adalah keseluruhan aspek kebijakan pembangunan yang berisiko bencana, meliputi kegiatan pada sebelum, saat, dan sesudah terjadi bencana yang mencakup 
pencegahan bencana, mitigasi, kesiapsiagaan, tanggap darurat, dan pemulihan kembali yang lebih baik akibat dampak bencana.

Pada wilayah Kelurahan Sisir, kebijakan penanggulangan bencana yang dipilih oleh Lurah adalah melakukan Implementasi Kebijakan Penanggulangan Bencana melalui Program Sisir Siaga Mandiri Relawan Tangguh (SMART). Implementasi kebijakan publik merupakan suatu proses melaksanakan keputusan kebijakan yang direncanakan secara baik, rasional, efisien, dan efektif dan tindakan-tindakan yang dilaksanakan oleh individuindividu dan kelompok-kelompok pemerintah dan swasta yang diarahkan pada pencapaian tujuan dan sasaran yang telah ditetapkan, (Setyawan, 2017: 92). Adapun model implementasi kebijakan publik yang digunakan dalam penelitian ini adalah model George C. Edward III. Edward III menegaskan bahwa terdapat empat faktor yang mempengaruhi keberhasilan dan kegagalan dari Implementasi kebijakan, (Widodo, 2017: 96) yaitu: 1) Komunikasi, 2) Sumber Daya, 3) Disposisi, dan 4) Struktur Birokrasi.

Faktor pertama adalah komunikasi kebijakan menurut Edward III (Widodo, 2017: 97) merupakan proses penyampaian informasi kebijakan dari pembuat kebijakan (policy maker) kepada pelaksana kebijakan (policy implementors). Informasi kebijakan publik perlu disampaikan kepada pelaku kebijakan agar para pelaku kebijakan dapat mengetahui, memahami apa yang menjadi isi, tujuan, arah, kelompok sasaran (target groups) kebijakan agar para pelaku kebijakan dapat mempersiapkan dengan benar apa yang harus dipersiapkan dan dilakukan untuk melaksanakan kebijakan publik agar apa yang menjadi tujuan dan sasaran kebijakan dapat dicapai sesuai dengan yang diharapkan.

Faktor kedua adalah sumber daya yang meliputi; sumber daya manusia, sumber daya anggaran, dan sumber daya peralatan, penekanan dalam hal ini adalah bagaimana kecakapan pelaksana kebijakan publik untuk melaksanakan kebijakan secara efektif. Faktor ketiga disposisi merupakan kemauan, keinginan, dan kecenderungan para pelaku kebijakan untuk melaksanakan kebijakan tadi secara sungguh-sungguh sehingga apa yang menjadi tujuan kebijakan dapat diwujudkan. Faktor keempat struktur birokrasi ini mencakup aspek-aspek seperti struktur organisasi, pembagian kewenangan, hubungan antara unit-unit organisasi yang ada dalam organisasi yang bersangkutan, dan hubungan organisasi dengan organisasi luar dan sebagainya. Oleh karena itu, struktur birokrasi mencakup dimensi fragmentasi dan standar operasi prosedur (SOP) yang akan memudahkan dan menyeragamkan tindakan dari para pelaksana kebijakan dalam melaksanakan apa yang menjadi bidang tugasnya, Edward III dalam Widodo (2017: 98106).

Kebijakan Penanggulangan Bencana yang dilakukan oleh Pemerintah Kelurahan Sisir adalah melakukan kerjasama dengan BPBD Kota Batu dimulai pada tahun 2016 membuat suatu program unggulan yang disebut dengan Program Sisir SMART. Program Sisir SMART dibuat berlandaskan Peraturan Daerah Kota Batu Nomor 2 Tahun 2016 Tentang Penyelenggaraan Penanggulangan Bencana dan Peraturan Kepala BNPB Nomor 1 Tahun 2012 tentang Pedoman Kelurahan Tangguh Bencana serta berdasarkan pada Surat Keputusan Lurah No 188.4/22/KEP/422.310.3/2016 tentang Pembentukan Sisir Siaga Mandiri Relawan Tangguh (SMART) Kecamatan Batu Kota Batu. Program SMART Sisir merupakan sinkronisasi antara Kelurahan Tangguh dan Kelurahan Siaga yang merupakan dua lembaga kemasyarakatan yang berbasis pada pelayanan terhadap masyarakat.

Pada Program Sisir SMART, Pemerintah Kelurahan Sisir dan Badan Penanggulangan Bencana Daerah (BPBD) membentuk relawan-relawan muda yang dilatih 
untuk selalu siaga, mandiri, dan tangguh dalam menghadapi bencana guna meningkatkan kualitas lingkungan hidup masyarakat di Kelurahan Sisir yang lebih baik kedepannya. Tujuan dari Program Sisir SMART yaitu dapat mengurangi resiko bencana di wilayah Kelurahan Sisir. Dengan adanya program SMART diharapkan mampu meningkatkan pengetahuan masyarakat dengan memberikan bimbingan dan latihan kepada masyarakat supaya lebih siaga, mandiri, dan tangguh dalam menghadapi dan mengatasi bencana.

Berdasarkan pemaparan diatas, maka tujuan penelitian ini untuk mendalami dan mendeskripsikan bagaimana implementasi kebijakan penanggulangan bencana melalui Program Sisir Siaga Mandiri Relawan Tangguh (SMART) di Kelurahana Sisir Kecamatan Batu Kota Batu dengan perspektif teori George C. Edward III meliputi; pola komunikasi, sumber daya, disposisi, dan struktur birokrasi.

\section{METODE PENELITIAN}

Penelitian ini menggunakan metode deskriptif dengan pendekatan kualitatif. Penelitian ini berusaha mengenali dan menggambarkan fenomena implementasi kebijakan penanggulangan bencana melalui Program Sisir Siaga Mandiri Relawan Tangguh (SMART) di Kelurahan Sisir Kecamatan Batu Kota Batu. Teknik penentuan informan menggunakan purposive sampling, (Sugiyono, 2017: 218). Informan terdiri dari Lurah Kelurahan Sisir, Staff Kasi Perekonomian dan Kesra yang menjabat sebagai Ketua Relawan SMART, Relawan BPBD Kota Batu yang Fokus pada Bagian Kebencanaan, Ketua RT. 03 RW. 12 Kelurahan Sisir, Anggota Pemuda Tangguh Kelurahan Sisir, dan salah satu Korban Bencana yang mendapat bantuan dari Program SMART.

Teknik pengumpulan data menggunakan observasi, wawancara dan dokumentasi seperti yang disampaikan oleh Sugiyono (2017: 225). Wawancara mendalam dilakukan dengan para informan yang benar-benar memahami dan terlibat langsung secara kelembagaan terkait dengan Implementasi Program SMART di Kelurahan Sisir. Observasi dilakukan dengan komprehensif, selanjutnya ditunjang dengan analisis dokumen terkait Program SMART berupa Laporan Program Kerja Kelurahan. Data yang didapat berupa data primer dan sekunder. Setelah data diperoleh, data dianalisis melalui tahapan reduksi data, penyajian data, dan penarikan kesimpulan. Uji keabsahan data menggunakan trianggulasi teknik yaitu dengan melakukan crosscheck data hasil wawancara, observasi, dan dokumentasi.

\section{HASIL DAN PEMBAHASAN}

Program Sisir Siaga Mandiri Relawan Tanguh (SMART) digagas oleh Lurah Kelurahan Sisir yang ke-15 yaitu Bapak Dian Fachroni Kurniawan, SE, M.SE, MA. Beliau mempunyai visi dan misi untuk menjaga kondisifitas wilayah Kelurahan Sisir dan mengantisipasi adanya bencana di wilayah Kelurahan Sisir. Oleh karena itu Bapak Dian Fachroni Kurniawan, SE, M.SE, MA. membuat sebuah kebijakan penanggulangan bencana melalui program Sisir SMART dengan berlandaskan pada Peraturan Daerah Kota Batu Nomor 2 Tahun 2016 Tentang Penyelenggaraan Penanggulangan Bencana dan Peraturan Kepala Badan Nasional Penanggulangan Bencana (BNPB) Nomor 1 Tahun 2012 Tentang Pedoman Kelurahan Tangguh Bencana.

Berlandaskan hal tersebut di atas maka pada tanggal 20 Nopember 2016 dengan Surat Keputusan Lurah No. 188.4/22/KEP/422.310.3/2016 tentang Pembentukan Sisir 


\section{REFORMASI}

Siaga Mandiri Relawan Tangguh (SMART) Kecamatan Batu Kota Batu, diluncurkan Program Sisir SMART dengan struktur Relawan SMART dan Tupoksinya masing-masing.

Program ini sudah berjalan tiga tahun semenjak diluncurkan tahun 2016 silam. Pemaparan Bapak Sasongko Fitra Adhitama, S.IP, MH. selaku Lurah Kelurahan Sisir yang sekarang menjabat mengatakan berkomitmen untuk terus melanjutkan program Sisir SMART ini demi menjamin masyarakat tanggap dan dapat mengatasi bencana yang setiap saat bisa terjadi.

Hasil penelitian yang telah dilakukan diperoleh data mengenai Implementasi Kebijakan Penanggulangan Bencana memalui Program SMART di Kelurahan Sisir sudah berjalan efektif ditinjau melalui empat faktor yang mempengaruhi keberhasilan dan kegagalan Implementasi kebijakan yang dikemukakan oleh George C. Edward III dalam Widodo, (2017: 97) yaitu; Komunikasi, Sumber Daya, Disposisi atau Sikap, dan Struktur Birokrasi.

Gambar Model Proses Implementasi Kebijakan Geoge E. Edward III

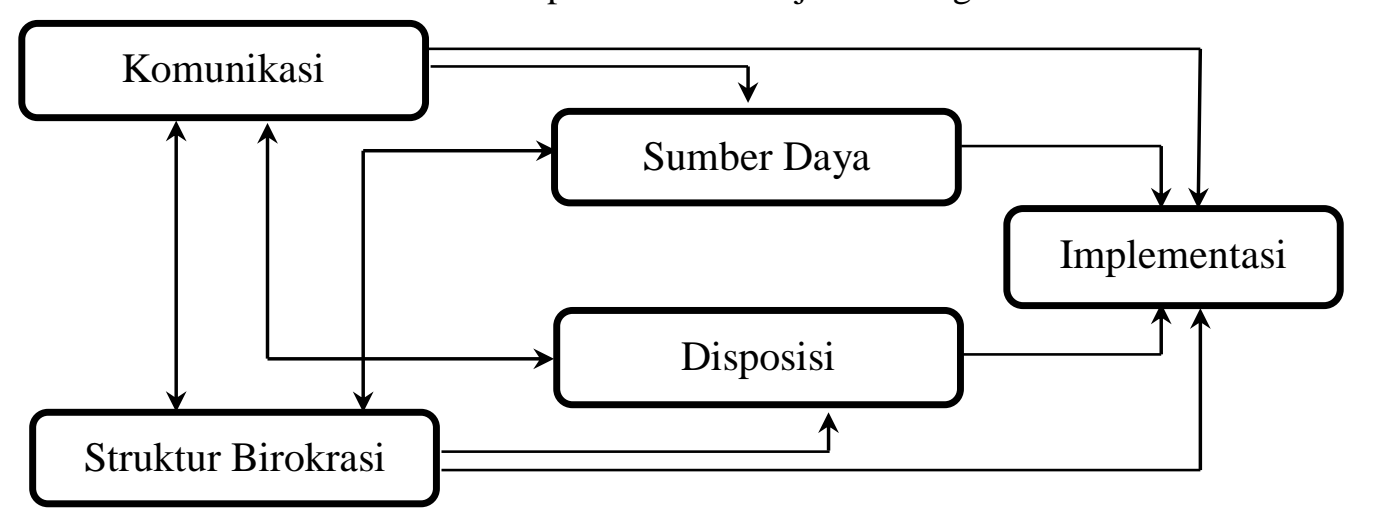

Sumber: Widodo, 2017: 107.

\section{Komunikasi}

Menurut Edward III (Widodo, 2017: 97), dalam komunikasi terdapat tiga hal penting yang harus diperhatikan untuk melihat apakah komunikasi yang dilakukan sudah berjalan dengan baik atau tidak. Tiga hal penting tersebut yaitu transmisi, konsistensi, dan kejelasan. Dimensi transformasi atau transmisi menghendaki agar Program SMART dapat di informasikan kepada Relawan SMART sebagai pelaksana, Masyarakat sebagai kelompok sasaran, dan BPBD sebagai pihak yang terkait dengan kebijakan. Dalam hal ini Lurah selaku pembuat kebijakan mentransformasikan atau mentransmisikan Program SMART kepada para staff dan relawan SMART melalui group WhatsApp SMART Sisir. Di group WhatsApp ini arahan, koordinasi, informasi mengenai kebencanaan diberikan oleh Lurah kepada para relawan.

Berikutnya dimensi kejelasan menghendaki agar Program SMART yang ditransmisikan kepada Relawan SMART sebagai pelaksana, Masyarakat sebagai kelompok sasaran, dan BPBD sebagai pihak yang berkepentingan langsung maupun tidak langsung terhadap program SMART dapat diterima dengan jelas yaitu dengan melakukan kerjasama dan koordinasi yang baik sehingga mengetahui apa yang menjadi maksud, tujuan, dan sasaran serta substansi dari Program SMART tersebut. Dimensi konsistensi menghendaki agar Program SMART yang ditransmisikan kepada Relawan SMART, Masyarakat, dan 
BPBD dapat dilaksanakan dengan konsisten. Dimensi konsistensi dibuktikan dengan kemauan dan kemampuan Para Relawan SMART untuk melaksanakan Program SMART.

Komunikasi dalam konteks penelitian ini digunakan supaya implementasi program SMART di Kelurahan Sisir dapat berjalan dengan baik. Jika dilihat dalam proses komunikasi yang dilakukan oleh Pemerintah Kelurahan Sisir sudah efektif menurut Edward III karena sudah memenuhi tiga dimensi penting didalamnya yaitu transmisi, konsistensi, dan kejelasan dimana proses komunikasi yang dilakukan dalam program SMART adalah dengan memberikan arahan dari Lurah kepada para staff dan relawan melalui group WhatsApp SMART Sisir. Berdasarkan penyajian data berikutnya bahwa hasil dari komunikasi yang baik, yang dilakukan oleh pemerintah Kelurahan Sisir melahirkan pola kerjasama dan koordinasi yang efektif antara BPBD, Relawan SMART, PKK, Linmas, TNI, dan Polri.

Komunikasi dalam bentuk kegiatan berupa sosialisasi juga dilakukan oleh Pemerintah Kelurahan Sisir. Pemerintah Kelurahan Sisir biasanya melakukan sosialisasi langsung di lingkungan masyarakat seperti melakukan kegiatan sharing Mitigasi Bencana bersama Para Mahasiswa dari Universitas Negeri Malang (kegiatan pengabdian mahasiswa) dan Relawan SMART Sisir. Selain itu, sosialisasi langsung juga dilakukan di lingkungan sekolahan seperti melakukan Kegiatan Peningkatan Kesiapsiagaan dan kapasitas SiswaSiswi SMAB (Sekolah Menengah Aman Bencana) yang diselenggarakan di SMA Immanuel Kota Batu. Selain itu, Pemerintah Kelurahan Sisir juga melakukan sosialisasi melalui beberapa media (baik media sosial, cetak maupun elektronik) seperti WhatsAap, Instagram, Facebook, Koran, Televisi, dan media lainnya dalam bentuk peringatan bahaya bencana, lagu peringatan bencana, cara perlindungan, mencantumkan nomor penting dan lain sebagainya.

\section{Sumber Daya}

Faktor sumber daya menurut Edward III (Widodo, 2017: 98) mempunyai peranan penting dalam implementasi program. Bagaimanapun jelas dan konsistennya serta akuratnya penyampaian ketentuan-ketentuan atau aturan-aturan (faktor komunikasi), jika para Relawan SMART sebagai pelaksana kebijakan (implementor) tidak didukung sumber daya untuk melakukan pekerjaan secara efektif, maka implementasi program tersebut tidak akan berjalan efektif. Manusia merupakan sumber daya yang sangat penting dalam menentukan keberhasilan suatu implementasi program. Setiap tahap implementasi menuntut adanya sumber daya manusia yang berkompeten sesuai dengan tugas dan fungsi yang telah ditetapkan. Sumber daya manusia yang berkompeten meliputi sumber daya manusia yang telah menempuh jenjang pendidikan formal dan memiliki pengalaman serta pelatihan tentang kebencanaan. Pentingnya kesiapan sumber daya manusia dalam melaksanakan suatu program kegiatan tidak bisa terlepas dari sumber daya yang memadai seperti peralatan dan anggaran. Sumber daya manusia berguna untuk menunjang pelaksanaan suatu program SMART di Kelurahan Sisir.

Dari hasil penelitian, faktor sumber daya dalam implementasi program SMART Sisir yaitu meliputi ketersediaan SDM yang berkompeten yaitu Relawan SMART yang memiliki pengalaman dan telah mengikuti pelatihan di bidang kebencanaan. Sumber daya lain seperti peralatan yang tersedia yaitu cangkul, tenda, HT, peralatan dapur umum, talitemali, tandu dan sebagainya yang diperlukan dalam penanggulangan bencana telah tersedia di Posko SMART. Kemudian sumber daya anggaran dalam implementasi Program 
SMART di Kelurahan Sisir tahun 2018 dianggarkan sebesar Rp 49.615.000,- yang dapat dikeluarkan sesuai dengan situasi dan keadaan di lapangan yang dapat menunjang dalam proses implementasi program SMART di Kelurahan Sisir. Anggaran tersebut dapat dikatakan merupakan anggaran minimum untuk penanggulangan bencana.

Meskipun sumber daya dalam Implementasi Program SMART sudah cukup memadai, namun harus tetap di tingkatkan lagi dengan adanya pembinaan, pemberian pendidikan dan pelatihan kepada Relawan SMART melalui kegiatan pembenahan di bantaran sungai brantas. Kemudian, Relawan SMART juga perlu meningkatkan kemampuan memanfaatkan sarana dan prasarana seperti cangkul, tenda, HT, dan peralatan lainnya yang diinventariskan di posko SMART dan disediakan oleh Pemerintah Kelurahan Sisir. Selain itu, perlu meningkatkan kerjasama yang baik antara pihak kelurahan dan BPBD, agar dalam pengadaan peralatan dan tersedianya anggaran terpenuhi sesuai rencana.

\section{Disposisi atau Sikap}

Faktor disposisi menurut Edward III (Widodo, 2017: 104) merupakan kemauan dan keinginan para pelaku kebijakan yaitu Pemerintah Kelurahan Sisir dan Relawan SMART untuk melaksanakan Program SMART di Kelurahan Sisir secara sungguhsungguh sehingga apa yang menjadi tujuan kebijakan dapat diwujudkan. Jika implementasi program SMART ingin berhasil secara efektif dan efisien, Pemerintah Kelurahan Sisir dan Relawan SMART tidak hanya mengetahui apa yang harus dilakukan dan mempunyai kemampuan untuk melaksanakan program kebencanaan, tetapi mereka juga harus mempunyai kemauan untuk melaksanakan kebijakan tersebut.

Dari hasil penelitian dapat diketahui bahwa disposisi yang dilakukan oleh Pemerintah Kelurahan Sisir dan Relawan SMART sebagai pelaksana program SMART di Kelurahan Sisir sudah efektif menurut teori Edward III, Bapak Sasongko Fitra Adhitama, S.IP, MH. selaku Lurah di Kelurahan Sisir memberikan disposisi kepada Bapak Daswaji Putro selaku Staff Bidang Kesra untuk menjadi ketua koordinator Relawan SMART. Selain itu, Relawan SMART juga selalu mengikuti arahan dari Pak Lurah dan dari BPBD. Dengan adanya disposisi yang diberikan dari Pak Lurah sendiri kepada para staff dan para relawan sesuai dengan tugas dan fungsinya, maka tentu akan terjadi kejelasan penanggung jawab dan pelaksana program SMART ini.

Kemudian, dari Pemerintah Kelurahan Sisir dan para Relawan juga memiliki komitmen tinggi untuk menjalankan program SMART sisir ini dengan optimal. Komitmen ini dibuktikan dengan kemauan dan kemampuan untuk melaksanakan Program SMART seperti mengadakan SMART Camp, Dapur Umum, Simulasi bencana, Forum Anak, Penghijauan dan lain-lain. Selain itu, Pemerintah Kelurahan Sisir berkomitmen untuk memonitoring dan memberikan arahan yang diperlukan dan melimpahkan kewenangan kepara para relawan SMART untuk siap dan tanggap terhadap bencana dengan memberikan pendidikan dan pelatihan kebencanaan yang telah dijadwalkan setiap tahunnya. Sehingga Pemerintah Kelurahan Sisir dan Relawan dapat menjadi pelayan yang baik bagi masyarakat, khususnya pelayanan dalam kebencanaan.

\section{Struktur Birokrasi}

Menurut Edward III (Widodo, 2017: 106), implementasi kebijakan bisa jadi belum efektif karena adanya ketidak efisien struktur birokrasinya. Struktur birokrasi ini mencakup aspek-aspek seperti struktur organisasi, pembagian kewenangan, hubungan antara unit-unit 
organisasi yang ada dalam organisasi yang bersangkutan, dan hubungan organisasi dengan organisasi luar dan sebagainya. Oleh karena itu, struktur birokrasi mencakup dimensi fragmentasi dan Standar Operasional Prosedur (SOP) yang akan memudahkan dan menyeragamkan tindakan dari para pelaksana kebijakan dalam melaksanakan apa yang menjadi bidang tugasnya.

Dari hasil penelitian terkait struktur birokrasi dalam pelaksanaan program SMART di Kelurahan Sisir sudah dilakukan dengan efektif terlihat dari adanya Surat Keputusan Lurah No. 188.4/22/KEP/422.310.3/2016 tentang Pembentukan Sisir Siaga Mandiri Relawan Tangguh (SMART) dan SK Nomor 188.4/12/KEP/422.310.3/2015 Tentang Pembentukan Pengurus Kelurahan Tangguh dan Siaga Kelurahan Sisir Kecamatan Batu Kota Batu. Selain itu, untuk tugas dan fungsinya para relawan sudah bekerja sesuai dengan SOP yang telah ditetapkan. Dari Pihak Pemerintah Kelurahan Sisir akan selalu berkoordinasi dengan para pelaksana program seperti BPBD, para Relawan, koordinator wilayah, PKK, Karang Taruna, Linmas, TNI dan Polri dengan jumlah 100 Anggota Relawan di dalamnya untuk mempermudah dalam pelaksanaan program SMART tersebut.

\section{Faktor pendukung dan faktor penghambat implementasi program SMART}

Implementasi Kebijakan Penanggulangan Bencana memalui Program SMART di Kelurahan Sisir tentu tidak terlepas dari faktor yang mendukung dan Faktor yang menghambat kelancaran dan keberhasilan program SMART tersebut. Adapun yang menjadi faktor pendukung dalam Pelaksanaan Program SMART di Kelurahan Sisir adalah adanya inisiatif dukungan dari masyarakat dan instansi yang menjadi Leading Sektor yaitu BPBD. Selain itu, dengan memberikan support dan reward kepada para relawan yang mengemban amanah dengan baik dapat menjadikan mereka lebih bersemangat dalam menjalankan tugasnya sebagai relawan yang tangguh. Kemudian adanya kerja sama dengan dinas-dinas terkait, seperti Dinas Kesehatan dan Damkar juga merupakan faktor pendukung dalam Pelaksanaan Program SMART di Kelurahan Sisir. Kemudian dengan adanya dukungan dari Lurah Kelurahan Sisir dan BPBD Kota Batu baik berupa finansial dan non finansial dapat membuat para relawan semakin giat dalam menjalankan Program SMART, dan tanpa mengabaikan dukungan dari semua pihak maka program ini dapat terlaksana dengan baik.

Sementara yang menjadi faktor penghambat dalam Pelaksanaan Program SMART di Kelurahan Sisir adalah kurangnya kesadaran sebagian masyarakat akan bahaya bencana. Sehingga belum menerapkan hidup sehat dan sadar lingkungan. Selain itu masih ada sebagian masyarakat yang bersikap tidak kooperatif atau tidak mau bekerjasama dengan Pemerintah Kelurahan karena cenderung takut dan belum mengerti bagaimana cara mengantisipasi dan melakukan evakuasi pada saat terjadi bencana. Pada saat pelaksaan program SMART, kendala yang terjadi yaitu di satu sisi Pemerintah Kelurahan Sisir sudah mulai mengurangi resiko bencana, tapi disisi lain ada masyarakat yang melakukan hal yang dapat menyebabkan potensi bencana seperti membuang sampah sembarangan, mengelola lahan tanpa memperhatikan kontur tanah, dan sebagainya. Kemudian faktor penghambat lainnya adalah sebagian masyarakat masih cenderung takut dan belum mengerti bagaimana cara mengantisipasi dan melakukan evakuasi pada saat terjadi bencana. Ditambah dengan kurangnya tenaga Relawan SMART dan alat pendukung seperti bahan makanan, peralatan medis, obat-obatan, ambulans, truk dan alat berat untuk mengangkut reruntuhan bangunan setelah pasca bencana saat evakuasi dilapangan. 


\section{REFORMASI}

ISSN 2088-7469 (Paper) ISSN 2407-6864 (Online)

Volume 9 Nomor 1 (2019)

\section{KESIMPULAN}

Program Sisir SMART merupakan sinkronisasi antara Kelurahan Tangguh dan Kelurahan Siaga yang merupakan dua lembaga kemasyarakatan yang berbasis pada pelayanan terhadap masyarakat, khususnya pelayanan kebencanaan. Berdasarkan hasil dan pembahasan diatas, maka dapat disimpulkan bahwa Implementasi Kebijakan Penanggulangan Bencana melalui Program SMART di Kelurahan Sisir dapat dikatakan sudah berjalan dengan baik, jika dilihat dari perspektif komunikasi, sumber daya, disposisi atau sikap, dan struktur birokrasi yang diperkenalkan oleh George C. Edward III. Faktor pendukung dari program ini yaitu adanya inisiatif dukungan dari masyarakat dan instansi yang menjadi Leading Sektor yaitu BPBD, serta kerja sama dengan stakeholder terkait seperti Dinas Kesehatan dan Damkar. Sedangkan faktor penghambatnya yaitu kurangnya kesadaran sebagian masyarakat terhadap bencana, kurangnya tenaga relawan dan peralatan pendukung pada saat evakuasi dilapangan, mengingat minimnya anggaran.

\section{DAFTAR PUSTAKA}

Data Bencana Kota Batu Tahun 2018.

https://www.bnpb.go.id/pengelolaan-data-bencana-berbasis-aplikasi-di-kota-batu Diakses tanggal 10 Oktober 2018.

Data Badan Penanggulangan Bencana Daerah Kota Batu. https://web.bpbd.jatimprov.go.id/bpbd-kab-kota/ Diakses tanggal 10 Oktober 2018.

Paltema, Lauri. 2017. China's changing disaster management regime. Jurnal China Information. Vol. 7 A.

Peraturan Daerah Kota Batu Nomor 2 Tahun 2015 Tentang Penyelenggaraan Penanggulangan Bencana.

Undang-Undang Nomor 24 Tahun 2007 Tentang Penanggulangan Bencana.

Setyawan, Dody. 2017. Pengantar Kebijakan Publik. Malang: Inteligensia Media.

Sugiyono. 2017. Metode Penelitian Kuantitatif, Kualitatif dan $R \&$ \& Dandung: Alfabeta.

Surat Keputusan Lurah No 188.4/22/KEP/422.310.3/2016 Tentang Pembentukan Sisir Siaga Mandiri Relawan Tangguh (SMART) Kecamatan Batu Kota Batu.

Widodo, Joko. 2017. Analisis Kebijakan Publik (Konsep dan Analisis Proses Kebijakan Publik). Malang: Media Nusa Creative. 